the author's own work. The volume is splendidly illustrated with plans, line blocks and half-tones. The chapters are arranged geographically-north Wales, west Wales, west and south Wales, the 'Foodvessel' phase in Britain, barrows in Glamorgan, etc. To start with there is a long introduction to the subject. Here the problems of the Bronze Age in general and barrows in particular are discussed and distributions considered. The stage is thus set for the account of a round barrow in Ysceifiog parish, North Wales, and at once we are made to see what must have happened there in the past.

Sites in the other geographical areas are treated in the same manner and we are thus given a vivid picture of how and in what order the processes connected with barrow-building took place-facts of construction that, having been appreciated, have sometimes "formed a basis for the recovery of an elaborate ceremonial". The various finds--pottery, tools, and the like-are, of course, carefully noted and their parallels elsewhere discussed. The Welsh monuments are not treated in vacuo; the importance of their geographical position vis-à-vis Ireland is stressed. "Life and Death in the Bronze Age" is well worth careful study not only for the many facts brought to light but also, as has been already said, for the vivid picture it affords of happenings which must have taken place in a millennium of the British Bronze Age.

M. C. Burkitt

\section{THE EARLIEST GEOLOGICAL TREATISE}

The Earliest Geological Treatise (1667)

By Nicolaus Steno (Niels Stensen). Translated from "Canis Carchariae Dissectum Caput", with Introduction and Notes by Dr. Axel Garboe. Pp. v +5I + 4 plates. (London: Macmillan and Co., Ltd., 1958.) 15s. net.

MODERN geology as an inductive science was 1 born in Italy in the latter part of the seventeenth century, the most famous of the pioneers being Nicolaus Steno (Niels Stensen, 1638-86), "the learned Dane", who had settled in Florence. In 1669 appeared his "De solido intra solidum naturaliter contento dissertationis prodromus" (the Prodromus to a dissertation concerning solids naturally contained within solids), the importance of which was recognized by Henry Oldenburg, secretary of the Royal Society, who published a translation (London, 1671).

Steno was led to study rocks through the examination of a shark's head which had been sent to him for dissection, and his account, "Canis Carchariae dissectum caput", published two years before the Prodromus, contains an appendix, which Dr. Garboe has translated, in which some of the essential elements of the later work are set down.

Recognizing the 'tongue stones' (glossopetrae) found in the rocks of Malta to be in all respects similar to the teeth of living sharks, he argues cogently that these and other fossils are the remains of once living aquatic animals, and he combats the view then commonly held that these bodies had grown within the rocks. This appendix consists of eleven 'observations' of sedimentary rock features, followed by six 'conjectures' in which the origins of the sediments, their fossils, cross-eutting veins, and departure from horizontality are deduced.
It seems strange to the geologist of to-day that the reaching of such fundamental and seemingly obvious conclusions was so long delayed, but their apparent conflict with the teachings of an all-powerful Chureh not only hindered the recognition of the significance of the evidence but also made men wary of voicing their opinions.

Dr. Axel Garboe is to be thanked for this pageby-page translation, which makes available to the English-speaking world "the earliest geological treatise". As frontispiece there is a reproduction of the portrait of Steno as a young man (Uffizi Gallery, Florence); also there is a copy of the title page of the 1667 work and its figure of a shark's head and teeth.

L. HAWKES

\section{PRINTED CIRCUITS}

\section{The Technology of Printed Circuits}

The Foil Technique in Electronic Production. By Dr. Paul Eisler. Pp. $x+405$. (London: Heywood and Co., Ltd., 1959.) 60s. net.

DRINTED circuits have been developed in the past I decade for use in equipment ranging from electronic computers to aircraft de-icing systems, and continue to replace manual wiring. In conjunction with component insertion machines they enable high rates of production to be attrined with low labour and inspection costs, and a greater uniformity of product than was possible by previous methods of wiring.

The book gives ample evidence of the author's position as a leading contributor to the technology of printed circuits, and the inventor of the printed foil technique now in general use.

The first two chapters describe early attempts at printed circuit production, and alternative methods such as spraying, stencilling, die-stamping and plating.

Chapters 3-8 contain a full account of the largescale manufacture of printed circuit boards, including the photography of the master drawing, the preparation of the raw material, the printing processes, and etching and cleaning. Chapter 9 gives details of the subsequent operations such as the deposition of protective coatings, soldering and encapsulation.

Chapter 10 contains an excellent description of the small-scale production of printed circuits, and the laboratory apparatus required.

The following three chapters deal with the design of printed circuits, the selection of foil and insulating board, the choice of components, automatic assembly and fault finding.

The final chapters describe methods of reducing the weight and size of electronic equipment, the use of printed components, and the application of printed eircuits to microwave systems and electronic devices. An excellent bibliography is included.

The wealth of practical detail given in the early chapters will be invaluable to those engaged in the manufacture and design of printed circuit assemblies, but the general reader would welcome more information about the use of printed circuits in various branches of the electrical industry, and their influence on system design, mechanical lay-out, and maintenance procedure.

However, this is the most comprehensive treatment of the subject generally available, and it is clearly destined to become the standard work of reference on printed circuit technology. J. C. Cluley 